\title{
The Zen Outlook on Life
}

\section{Reiho Masunaga}

\section{Meaning of Zen}

Zen helps man to find his true self through zazen(crosslegged sitting) and to vitalize this self in daily life. It has three basic elements: 1) the practice of zazen, 2) the finding of the true self, and 3) the use of this self in day-to-day activities. Zazen stresses correct posture, harmonious breathing, and relaxed body and mind. It makes us more sharply aware of our true self- sometimes called the Godhead or Buddha-nature. But this awareness - the enlightenment experience or satori-must not be a source of selfish pride. Satori has to permeate daily life. To realize itself. it has to contribute to social betterment.

The Zen man, then; tries 1) to live fully in this moment, 2) to stand above dualism while using it freely, 3) to value his body as an instrument of training, 4) to strengthen his human-essence awareness, and 5) to work in the world for the common good.

These characteristics are underlined in a number of Zen sayings. For example :

1) "In life we express full function; in death we express full function." Engo (-1335).

2) "The perfect way is not difficult. Just avoid discrimination. If there is no love and hate, this world would be completely bright." Sōsan $(-606)$.

3) “One gains the Way with this body." Dōgen (1200-1253).

4) "If we are our master everywhere, each place we stand is true." Rinzai (-867).

5) "Benevolence is the universal law." Dōgen.

In the Genjōkōan section of Shōboggenzō, Dōgen summed up these points in the following passage: 
"To study Buddhism is to study the self.

"To study the self is to forget the self.

"To forget the self is to be enlightened by all things.

"To be enlightened by all things is to be free from attachment to the body and mind of one's self and of others.

"It means wiping out even attachment to satori.

"Wiping out attachment to satori, we must enter actual society."

Of the five Zen schools that developed in China, Rinzai and Sōtō are the ones most active in Japan today. Japanese Zen also includes the Ōbaku school, but its influence is not so extensive as the two larger schools.

The Rinzai school was founded by Rinzai Gigen (Lin-chi I-hsüan) in China and brought to Japan by Eisai (1141-1215). It aims at satori through the kōan, a formalized problem. Even in zazen it emphasizes kōan solving. This emphasis on the kōan tends to impart a step-like character to Rinzai Zen. The essentially abrupt nature of Zen gets blurred.

The Sōtō school originated with Tōzan (Tung-shan 807-869) and Sōzan (Ts'ao-shạn 440-901). Dōgen transmitted its teachings to Japan. In Sōto the basic emphasis falls on the self-identity of practice and enlightenment. Thorough practice is its watchword. It sees zazen and satori as an integrated whole. Understanding this unity requires effort and insight. One misstep can turn Sōtō Zen into a from of naive naturalism.

The Öbaku school was linked to Rinzai in China. It came to Japan during the Tokugawa period through Ingen (1592-1693). It combines both Zen and Nembutsu elements. The synthesis, however, is not thorough. Zen and Art

Since coming to Japan, Zen has had far-reaching impact on the life of the Japanese. It has had a particularly vital influence on the artson architecture, sculpture, painting, calligraphy, gardening, flower arrangement, yōkyoku, Noh, haiku, and the tea ceremony. Out of this came a unique Zen art. This art conveys simplicity, profundity, creativity, and vitality.

The plain pillars of Zen inonastery architecture are an example of 
simplicity. Avoiding decorative gild, they show the natural grain of the wood. They remind us of one of Zen's basic aims- " to show one's natural face." The garden at Ryōanji in Kyōto and the sumie of Sesshū (14201506) are similarly stripped of the extraeous.

This is not a shallow simplicity. Just as the rocks at Ryōanji are buried deep, the profound comes with the simple. Bashō in his haiku and Zeami (1363-1443 or 45) in his Noh plays write from the same depth. Bashō particularly makes us sense the profundity dwelling in the apparently simple.

When we show our natural face, we express our inherent originality. This is creativity. The Zen impulse toward fresh expression enables the artist to strike out for himself once he has mastered the form. Sesshü learned from Josetsu and Shūbun in Japan and from Kakei in China and then moved on to make his unique contribution. Zen encourages the disciple to move on to the original and creative. The Hekiganroku, for example, says: "If the wisdom of the disciple is the same as the master's, the virtue of the master diminishes by half. The discipe repays his master only by transcending him." A Western student of Zen, Professor E. Herrigel, called this "to climb on the shoulders of the teacher (auf des Lehrers Schultern zu steigen)."

When the Zen impulse overflows, rigid form, there is vitality. The calligraphy of Ryōkan and Hakuin underlines the free flow and vigor of Zen art. John Dewey's phrase "vital freedom" fittingly describes this characteristic.

We can find simplicity, profundity, creativity, and vitality, with varying emphases, in all Zen art. They are also, of course, elements of the Zen life.

\section{Zen and Life}

In the Zen monasteries there is simplicity in the austere, one-soupone-vegetable life of the monks. Yet, as in Zen art, the simple and the deep are back to back. The apparent simplicity of the daily routine is intertwined with some of the deepest insights into the human condition. 
It is no accident that the old Zen teachers, while upholding "no dependence on words and letters," produced a torrent of books and manuscripts. To explain their profound experience and understanding, they pushed words and letters as far they would go. Dōgen's Shōbōgenzō, for example, centers on trying to put across the non-duality of "original enlightenment" and "superior training."

"Superior training" implies not only following tradition but transcending it. It means to find what lives within form. Keizan (1268-1325) has some pertinent words here:

"The body of Śākya is still warm;

"The faint smile of Kā'syapa retains its freshness-

"To let us know the unchanging by a flower gesture.

"And to teach us eternity in a smile."

To the extent that we awaken to the living core, we are free: we are creative. To gain this awakening-the freedom from conditioned tyranny-we have to leave much behind. Some of our most cherished attachments must be dropped if they keep us in bondage. In Zen terms Rinzai put it this way: "If on your way you meet the Buddha, kill him. If on your way you meet the patriarchs, kill them."

When we can put our deepest attachments into true perspective, we function fully. We start living as we should. Vitality emerges naturally. From our own inner resources we act with vigor and directness against all that would make us less than human. Zen compares it to living anew after letting go and falling to the bottom of a thousandfoot cliff. Fuku expressed this mood of vital freedom in the following words:

Let a man come from the bright side,

And I'll dispose of him on that side;

Let him come from the dark side,

And I'll dispose of him on that side;

Let him come from every possible direction,

And I'll dispose of him like a whirlwind;

Let him come from the sky, 
And I'll dispose of him like a flail.

Much of Zen's appeal today, I believe, stems from this uncompromising view of the whole man. Many Western thinkers are drawn to Zen because it promises fulfillment without the supernatural. Its basic approach could supplement and strengthen such Western ideas as existentialism in Europe and pragmatism in the United States. In an increasingly complex and mechanized world, perhaps there is need for a teaching that helps man toward being himself. Zen seems well suited to restore the sense of life to many who have lost it - to stimulate the creative in man that alone can guarantee his survival.

Among some scholars Zen is regarded as mysticism, and they find this attractive. But can Zen be judged is this way? If Zen is mysticism devoided from reality, has can we live in vital freedom with actual society? In this space age Zen would then also conflict with science. Science forms the basic mood of the present. The wisdom taught by Buddhism does not exclude scientific knowledge but envelops it. A religion conflicting with science is not a religion for the present, Zen transcends the dualism and truly vitalizes the value of science.

"No dependence of words and letters" does not mean a retreat from knowledge. Rather it indicates no enslavement to words and letters and the bringing of the true meaning of life. Science, of course, is not omnipotent. It has its own limits. In the spiritual background of Zen there is the wisdiom of śunyatā. Śūnyatā wisdom does not depend on anything does not become enslaved to anything, and does not cling to delusion. It denies a rigid view of substance. To consider Zen as mysticism and to be fascinated by this is to rob Zen of life.

Clouds float quietly around the mountain peak, Water runs vigorously down the ravines below.

Kaiankokugo iv. 